\title{
E-Government in Albania
}

\author{
Anila Gjonaj \\ University of Tirana, Faculty of Social Science, Department of Political Science \\ Email: anilagjonaj@yahoo.com \\ Ermelinda Shehaj \\ University of Tirana, Faculty of Social Science, Department of Political Science \\ Email: ermelindashehaj@yahoo.com
}

\section{Doi:10.5901/ajis.2016.v5n3s1p456}

\begin{abstract}
Douglas Engelbart, the inventor of the computer mouse said "The digital revolution is more important than the invention of writing ... ". This expression in the beginning seemed like an exaggeration pleasant, but today it is a reality in every area of life. The Albanian government has initiated a program "Digital Albania" as part of govern program for the period 2009-2013continued. This program essentially it's not concerns the use of a computer, database or interfaces website, but above all related to their use to promote effective and democratic governance, improving the educational system, information and services that the government provides to its citizens. In Albanian conditions, this initiative is a huge undertaking that requires titanic effort to succeed with the right pace. They have been and are great difficulties after such an effort requires particularly more energy, time and money. It has sought and continues investment major in human resources, the adoption of appropriate legal framework, in planning and establishment of appropriate institutional structures, investment direct technology, etc. Of course Albania continues have shortcomings communication between politics, business, education and producers technology. This is partly due to traditional roles various interest groups, but also due to the fact that Albania did not inherit any tradition, not only technology, but also the potential impact of technology on organizational development and all major industries.
\end{abstract}

Keywords: digital, governance, programs, information, system.

\section{Introduction}

Technologies of Information and Communication Technology (ICT) play an important role in achieving the strategic goal for governance to be always the best. Ensure governance through ICT electronics (e-governance), which is nothing but an instrument for a more effective, more transparent and efficiently. Today, the main benefit of e-government technology systems seen in building an open information society through the provision of a wide variety of public services on-line, by promoting partnerships public and private only for some benefits in common. ICT and priorities in European level are too outlined in Europe 2020. Strategy for increase and stable of economy in the European Union, prepare for the challenges in future decade. Digital Agenda for Europe (DAE) 20, it's connected direct with field of technology of information and Communication ${ }^{1}$.

In analogy with EU priorities of policies, development of ICT and digital agenda are part of program in government of Albanian for period 2013 - 2017. Its set that government must do work in main guidance by targets decided to be measurable:

The first, for increase and promotion the electronics services for citizens, business and administration.

The Second, for use the ICT in education (trained youth).

The third, consolidation of digital infrastructure in all territory of Albania by respected with rigorously principles of European to be competition, cheap and honest².

ICT it's currently a main driving forces to economy and growth of GDP in European Union that come from ICT

\footnotetext{
1 Një Axhendë Dixhitale për Evropën, COM(2010)245, miratuar 19.05.2010, EC, http://www.digitalEvrope.org/DesktopModules /Bring2mind/DMX/Download.aspx?Command=Core_Download \&entry/D=157\&Portalld=0\&Tabld=353

${ }^{2}$ http://www.akshi.gov.al/images/Programi_Qeverise.pdf
} 
sector. Investments and innovation in ICT that are expected to contribute in growth and productivity in European Union is with 45\% until 2020. In Albania the sector of electronics communication as part of ICT give a contribution 5-6\%.in GDP.

\section{Methods}

Political research study is interdisciplinary and therefore the methods used are borrowed from other scientific fields. All these disciplines and their methods are interdependent and also interfere with other factors, which should not be overlooked. But one of the ways search more frequent and more widespread in Political Science is undoubtedly the comparative method, also known as" the queen methods of Political Science.

\section{E-Government and e-Participation}

The European development model is closely interrelated with the economic development of an information society. This transformation involves engaging the citizenry more fully while at the same time becoming more cost effective and efficient with the resources it currently has and consumes. The Government of Albania has identified ICT as an enabler for the social and economic development of the country. For over a decade, the Government of Albania has gradually been introducing ICTs and new technologies tools in the day-to-day work of Central Ministries and Government agencies. Such activities involved the active support of the donor community in the country ${ }^{3}$.

Reports periodic to UNPAs (Network of administration public to UN) make a rating to e-government Readiness index, and e-participation. Results for web access and services online issued. This is on basis on survey to Site official to website.

In the table there are e-government index in Albania from 2003 - 2014

Table 1:4

\begin{tabular}{|l|c|c|c|c|c|c|c|}
\hline Year & $\mathbf{2 0 0 3}$ & $\mathbf{2 0 0 4}$ & $\mathbf{2 0 0 5}$ & $\mathbf{2 0 0 8}$ & $\mathbf{2 0 1 0}$ & $\mathbf{2 0 1 2}$ & $\mathbf{2 0 1 4}$ \\
\hline e-government Index & 0.311 & 0.340 & 0.3732 & 0.4670 & 0.4519 & 0.5161 & 0.5046 \\
\hline Web measurement sub index/online service & 0.083 & 0.162 & 0.1615 & 0.3913 & na & 0.425 & 0.4488 \\
\hline Telecommunication sub Index/ infrastructure & 0.049 & 0.058 & 0.068 & 0.1251 & na & 0.337 & 0.3548 \\
\hline Human Capital sub Index & 0.80 & 0.80 & 0.89 & 0.8869 & na & 0.7863 & 0.7100 \\
\hline
\end{tabular}

Compare the index of e-government with Europe and world in average from 2010 -2014

Table 2: ${ }^{5}$

\begin{tabular}{|l|c|c|c|}
\hline Year / compare & $\mathbf{2 0 1 0}$ & $\mathbf{2 0 1 2}$ & $\mathbf{2 0 1 4}$ \\
\hline Albania & 0.4519 & 0.5161 & 0.5046 \\
\hline Average Europe & 0.5566 & 0.6574 & 0.6936 \\
\hline Average World & 0.4406 & 0.4882 & 0.4712 \\
\hline
\end{tabular}

Compare the index of e-participation with Europe and World in average from 2010 -2014

Table 3: ${ }^{6}$

\begin{tabular}{|l|c|c|c|}
\hline Year / compare & $\mathbf{2 0 1 0}$ & $\mathbf{2 0 1 2}$ & $\mathbf{2 0 1 4}$ \\
\hline Albania & 0.1286 & 0.105 & 0.5294 \\
\hline Average Europe & 0.5566 & 0.6574 & 0.6936 \\
\hline Average World & 0.4406 & 0.4882 & 0.4712 \\
\hline
\end{tabular}

3http://webcache.googleusercontent.com/search?q=cache:http://ihakrama.epoka.edu.al/mat/eGovernment_ihakrama_dhoxha_oasilkan.pdf

4 UN reports: http://unpan3.un.org/egovkb/ProfileCountry.aspx?ID=2

${ }_{5}^{5}$ UN reports: http://unpan3.un.org/egovkb/ProfileCountry.aspx?ID=2

6 UN reports: http://unpan3.un.org/egovkb/ProfileCountry.aspx?ID=2 
Note that in periodic reports of UN tell us that have had an amendment to methodology, thing that can contribute in outcome with landing to indicator for e-participation. In order Albania it's in the place 59 according to UNPAs for 2014.

ICT and digitization processes of modernization in supporting:

- Economic processes, through the improvement of production capacities based on ICT, knowledge economy and the creation of start-ups, development of innovative activities and smart cities and communities, increasing productivity in agriculture, social enterprises etc;

- Social processes, the improvement of services provided to the community and production of the common good, in promoting and facilitating social innovation, creation and exploitation of common resources, and funding etc;

- Institutional and administrative processes, via e-Government services, digital identity, facilitating interagency interoperability, simplify the institutional and administrative procedures, provision of ancillary services online, participation in decision-making of citizens and business alike.

\section{Results and Discussion}

"Since the advent of a word wide revolution in information and communication technologies many governments in the world have become aware of the potential of using the information and communication technologies particularly internet as a tool in enhancing their services and increasing their efficiency in terms of accessing information and transaction services. These electronic services often referred to as e-Government"7. Albania govern is working hard in that field. Major priorities of this strategy that is undertaking from Albania govern are: improving national infrastructure information and communication technology; e-government development and the creation. The multipurpose cadastre. These are long-term priorities, provided and NSDI and extended time in 2015-20208.

1. Improvement of national infrastructure and information technology communication, as the backbone of the rapid development of the Information Society and increased electronic readiness.

2. Development of Electronic Government and public e-services interactive delivery through internet for citizens and business.

3. Implementation of national policy for the establishment of the National Infrastructure Spatial Data (NSDI) and multipurpose cadastre through:

In Digital Agenda for Europe there are identified seven priorities to relate closely with one of them to another:

- A join digital market in EU;

- Standard and interaction;

- Trust and Security;

- Access in internet;

To popular as "crowd sourcing" and "crowd founding"

- Search and innovation;

- Improvement to knowledge and capability;

- Benefits from ICT for all society

The development of technology of information and communication (TIK) affected by the approximation of legislation with EU legislation or international. They are designed and commitments adopted in accordance with the MSA, a package of laws in society information. Filling Legislation and adapting it according to the best practices International is one of the priorities in priority to the development of society Information and communication?.

\section{Conclusions}

The very nature of ICT technology of general interest but also because of the impact growing that the use of ICT, Digital Agenda 2015-2020 extends the effects at all sectors of the economy and social life. Development of the Information Society in Albania is a common objective of all actors, such as public sector, academia, NGOs, civil society and private

\footnotetext{
${ }^{7}$ Gartner, A. (2007). Majority of e-Government Initiatives Fail or Fall Shor of Expectations. Inc's Executive Programs. San Diego.

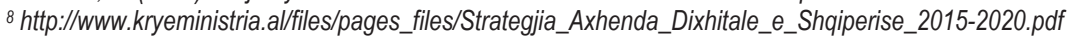

9 http://www.uamd.edu.al/new/wp-content/uploads/2013/01/ROLI-I-TEKNOLOGJIVE-T\%C3\%8B-REJA-T\%C3\%8B-INFORMACIONITN\%C3\%8B-NDIHMES\%C3\%8B-T\%C3\%8B-SIGURIS\%C3\%8B-KOMB\%C3\%8BTARE.pdf
} 
organizations. The successful realization of this objective relates to harmonization development among all sectors and actors.

But in conclusion of analysis the challenges for digital agenda in Albania 2015-2020 still need for:

- Obverse and improvement legal and regulatory that to answer fast this dynamic development to the ICT field and creation a join digital market (regional and global);

- Development and infrastructure ICT must to orientate in growth and extension access broadband to fast and super to fast in all territory and country;

- Increase and penetration the web-site in family and business and in frame to reduction it the digital gap;

- Development the right roads to deliver the public services through points to contact online and offices with one stop shop;

- Implementation resources to interoperability to systems and services;

- Benchmarking ICT as a warranty for development to integrate and to sustainable the information society in to all sectors;

- Incentive private sector in ICT;

- Development in infrastructure of public administration in central and local level;

- Increase to capacity and knowledge for ICT for administration and users citizens and business;

- Co-operation interagency and in regional and global level for an internet information to secure;

\section{Reference}

Gartner, A. (2007). Majority of e-Government Initiatives Fail or Fall Shor of Expectations. Inc's Executive Programs. San Diego.

Një Axhendë Dixhitale për Evropën, COM(2010)245, miratuar 19.05.2010, EC, http://www.digitalEvrope.org/DesktopModules /Bring2mind/DMX/Download.aspx?Command=Core_Download \&entry|D=157\&Portalld=0\&Tabld=353

UN reports: http://unpan3.un.org/egovkb/ProfileCountry.aspx?ID=2

Strategjia ndërsektoriale "Axhenda Dixhitale e Shqipërisë 2015-2020": http://www.kryeministria.al/files/pages_files IStrategjia_Axhenda_Dixhitale_e_Shqiperise_2015-2020.pdf

Roli dhe zhvilimi i e-gov në Shqipëri: http:///www.dap.gov.al/images/revistat/revista4.pdf

A comparison of e-government progress in Turkey and Albania: http://webcache.googleusercontent.com/search?q=cache: http://ihakrama.epoka.edu.al//mat/eGovernment_ihakrama_dhoxha_oasilkan.pdf

Programi i Qeverisë 2013 - 2017" http://www.akshi.gov.al/images/Programi_Qeverise.pdf

Strategjia Ndërsektoriale për Shoqërinë e Informacionit,fq 15, http://www.akshi.gov.al/?crd=7,Lng1

Roli i teknologjive të reja të informacionit në ndihmesë të sigurisë kombëtare: http://www.uamd.edu.al/new/wpcontent/uploads/2013/01/roli-i-teknologjive-t\%c3\%8b-reja-t\%c3\%8b-informacionit-n\%c3\%8b-ndihmes\%c3\%8b-t\%c3\%8bsiguris\%c3\%8b-komb\%c3\%8btare.pdf 